\title{
THE PROCESS APPROACH IN THE FINANCIAL MANAGEMENT OF INSURANCE FIRMS
}

\author{
Lech GĄSIORKIEWICZ \\ Warsaw University of Technology, Faculty of Management, Warsaw, POLAND \\ e-mail: lech.gasiorkiewicz@pw.edu.pl
}

\begin{abstract}
The significance of insurance activity is constantly growing, generating new problems and posing new challenges. One of these challenges is meeting the growing requirements and expectations of customers. This requires the efficient management of insurance companies, which means the necessity to resort to modern management concepts, particularly the concept of process management and its related instruments. The article presents the results of research carried out at the Faculty of Management of the Warsaw University of Technology regarding process management in insurance companies. The distinctness of insurance activity and its financial management is discussed and its following aspects presented: the identification of insurance activity processes encompassing the management of basic and auxiliary processes; the model of the financial management process of insurance companies; the relationship between the financial management process and other processes implemented in insurance companies; financial situation assessment measures for insurance companies, and the financial management process.
\end{abstract}

Keywords: process management, process identification, financial management process, financial management process model, process relationships, process evaluation measures.

JEL Classification: G22.

\section{$1 \quad$ Introduction}

The development of modern insurance companies is conditioned by cyclical and social factors. Economic factors resulting from the complexity of economic conditions have their source in a multitude of processes and phenomena affecting insurance companies, the constantly growing pace of change and strong links between the insurance market and the entire capital market as well as their interdependencies.

Social factors are a consequence of the changing and constantly growing needs and requirements of customers. Meeting these challenges requires the implementation of new management concepts to achieve market and financial success. In this context, process management deserves attention.

Process management is an area of interest for practitioners and is also reflected in a number of publications, both domestic: (Adamczyk and Trzcieliński, 2003; Bitkowska, 2019; Borowiecki and Kiełtyka, 2011; Cyfert, 2006; Grajewski, 2012; Hofman and Skrzypek, 2010; Nosowski, 2010, Nowosielski, 2009; Rummler and Brache, 2010; Szczepańska, 2016; Trocki, 2010) and international (Balanescu, Voicu and Beliciu, 2014; Becker, et al., 2014; Burlton,
2001; Chang, 2006; Dalikova and Dolezalova, 2012; Davenport, 1994; Hammer and Stanton, 1999; Houy, et al., 2010; Jeston and Nelis, 2011; Klun and Trkman, 2018; Simões, et al., 2015; Smart, Maddern and Maull, 2009; Stemberger, Kovacic and Jaklic, 2007; Talwar, 1993; Tucek, 2009; Van Der Aalst, La Rosa and Santoro, 2016; Weske, 2007). However, there are few publications on the applications of process management in individual sectors, including the insurance sector (Gąsiorkiewicz, 2018; Gąsiorkiewicz, 2019; Śliwiński, Karmańska and Michalski, 2015).

The development of process management, its foundations, principles, methods and solutions has resulted in the emergence of process management as a new field of management. Focusing on implemented processes allows for the achievement of designated goals as well as to meet the needs and expectations of both external and internal customers.

The identification and modelling of processes implemented in organizations create the conditions for their optimization and for the elimination of non-value-creating elements, and also allows for the efficient management of these processes.

The purpose of this article is to look for answers to the following research questions: 
- What constitutes the distinctness of insurance activity?

- How can the process architecture of the insurance business be presented?

- What is the structure of the financial management process of insurance companies?

- What is the relationship between the financial management process and other implemented processes in insurance companies?

- What measures can be used to assess the financial situation and the management process of the finances of insurance companies?

\section{The process approach in managing insurance companies}

Insurance companies (like other financial institutions) operate in a changing environment. Customer expectations regarding new insurance products are increasing. Customers that are becoming more and more assertive expect the highest quality, even in the case of traditional products. Higher customer requirements are addressed to insurance companies in handling insurance claims. There are also significant changes in the financial market on which insurance companies carry out investment activities. As a result, insurance companies are looking for new solutions in the area of management. "Process management is a response to: the growing turbulence both in environment and within the company, the increase in the complexity of internal and external processes, the individualization of customer needs and expectations, short product life cycles and the increase in the importance of intangible assets in creating a competitive advantage. The process approach exists within the framework of modern management trends that promote: decentralization, orientation towards the customer, reorientation of the organizational structure from vertical to horizontal, and the interfunctionality of the issues of enterprise management - which contributes to the increase of the organization's effectiveness in changing conditions." (Trocki, 2010).

The implementation of process management in insurance companies provides a greater dynamism to their operations than provided by the classical forms of management, and can bring a number of additional benefits, such as: an increase in the value and competitiveness of insurance companies, increasing innovation, a significant increase in the efficiency of processes, the more rational use of resources, meeting the expectations of internal and external clients, communication improvement, the embedding of mechanisms of continuous improvement in the strategy of the insurance company and greater emphasis on developing employee skills.

The implementation of process management is a complex undertaking, implemented in stages. The stages of implementing process management according to various authors are presented in Table 1.

Table 1. The stages of implementing process management

(Source: Bitkowska, 2019)

\begin{tabular}{|c|l|}
\hline Author & \multicolumn{1}{c|}{ Stages of process management } \\
\hline \multirow{4}{*}{ (Talwar, 1993) } & - defining the organization's strategy, \\
& - acquiring and developing such organizational competences and skills \\
& necessary for the effective implementation of strategy, \\
& - designing basic processes that support the development and use \\
& of organizational competences, \\
& - implementation of the process structure. \\
\hline \multirow{3}{*}{ (Houy, Fettke and Loos, 2010) } & - development of process management strategies, \\
& - process definition and modelling, \\
& - implementation of processes in the organization, \\
& - monitoring and controlling the implementation of processes, \\
& - process optimization and improvement. \\
\hline
\end{tabular}


Table 1. The stages of implementing process management (cont.)

(Source: Bitkowska, 2019)

\begin{tabular}{|c|l|}
\hline Author & \multicolumn{1}{c|}{ Stages of process management } \\
\hline & - strategy formulation, \\
& - description and analysis of the current organization, \\
(Rummler and Brache, 2010) & - description and analysis of currently running processes, \\
& - preparing a map of processes and their measures, \\
& - preparing a description of each function in the structure, \\
& - preparation of job descriptions, \\
& - designing an employee effectiveness system for each position, \\
\hline
\end{tabular}

The approaches presented in Table 1 "indicate repetitive stages, which include process identification, modelling, monitoring as well as controlling and steering. It is also important to consider process management when taking into account specific aspects such as process planning, process control, and process improvement." (Bitkowska, 2019).

\section{The distinctness of the financial management of insurance companies}

Insurance activity is characterized by particular features, which include:

- accepting, in exchange for consideration (premiums), the financial risks of customers,

- financing from collected premiums,

- a high level of decision-making risk and the significant weight of substantive decisions pertaining to: product design, contract terms, tariffs, and so on,

- a variety of insurance services (products), which generates a significant and varied knowledge need in the medical, engineering, financial, and legal areas,

- a long contractual period and unchanging fixed price (premiums) - high interest rate risk,

- the intangible nature of the products, the shape and perception of which is created during their sale,

- the large scale of leverage (debt financing) and high financial leverage, though of a specific character,
- and the inseparability of services from the entity offering them (insurance company).

The distinctness of insurance activity is reflected in the financial economy of insurance companies, which differs significantly from the financial economy of other business entities. Among the basic factors determining its distinctiveness are:

- the deterministic nature of income streams (revenues) and the stochastic character of the outflow of funds (costs) related to the payment of claims /benefits, with randomness applying to both the moment of the random event and the amount of the future claim,

- the accumulation of special-purpose reserves - for the payment of claim beneficiaries - which constitute the basic source of financing for an insurance company,

- shaping the investment portfolio in such a manner as to fully cover the special-purpose reserves, which are responsible for ensuring the financial equilibrium of the insurance firm.

The distinctness of the financial management of insurance companies is also associated with their 'production cycle', since in such companies there is a reverse 'production cycle': first, revenues (premiums) are achieved and then costs (claims) are incurred. In addition to the reverse 'production cycle', distinct features of the financial management of insurance companies are:

- the intangible nature of the insurance product (promise of payment compensation/benefits in the 
event of a random event as foreseen in the insurance contract),

- difficulties in predicting the size of financial flows,

- the inability to precisely determine the actual state of assets and liabilities,

- the use of specific financial tools (e.g., insurance technical reserves, franchises, deductibles, reinsurance),

- the special role of own resources (equity),

- the strong financial correlation between assets and liabilities,

- and the need to comply with statutory financial security requirements.
The specificity of the financial management of insurance companies presented should be taken into account when developing solutions for identifying insurance business processes.

\section{Identification of the processes of insurance company activity}

Process identification is one of the first stages of implementing process orientation in a given enterprise and means recognizing the types of actions in the given organizational unit and their appropriate categorization.
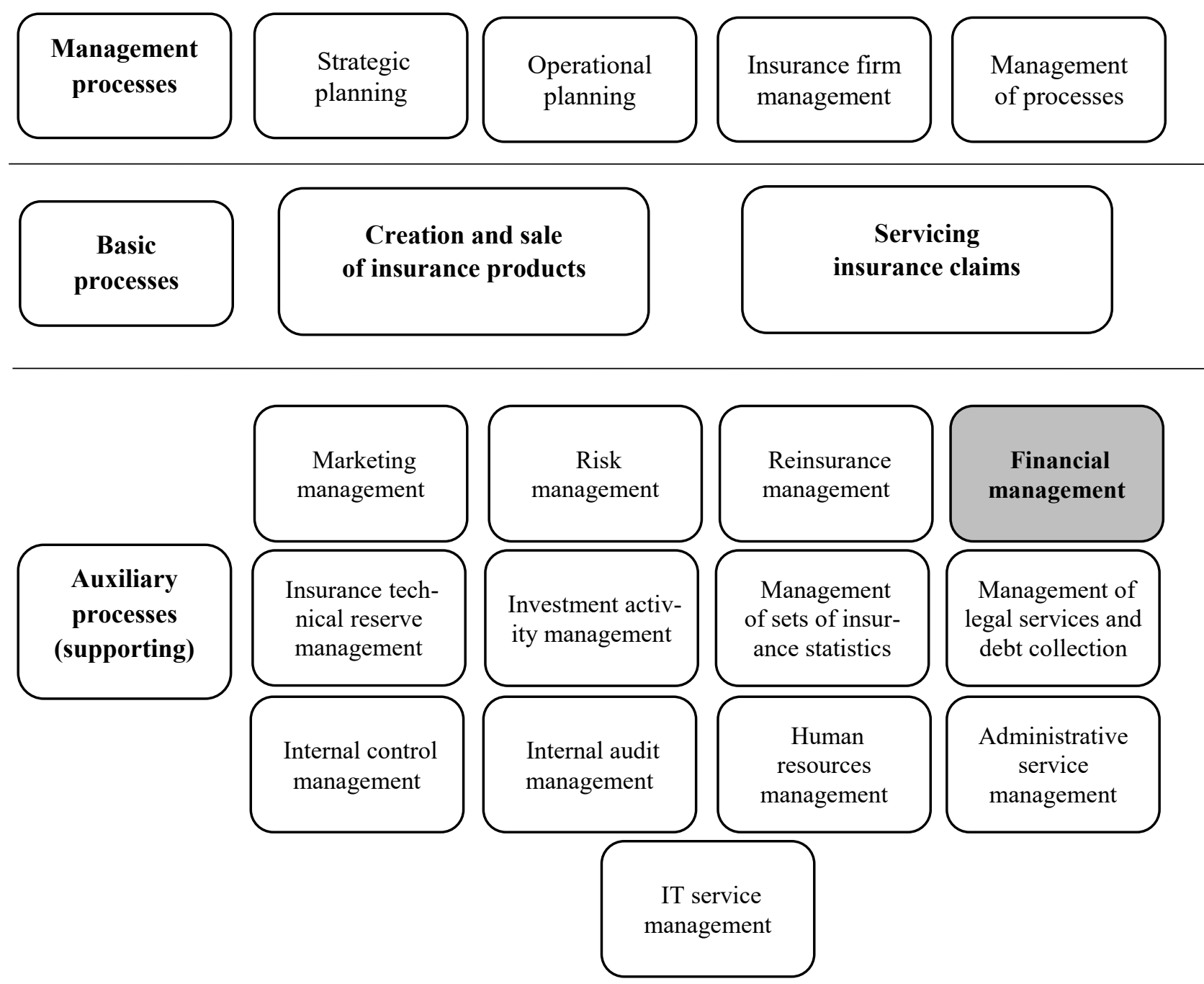

Figure 1. The process architecture of insurance activity (Source: Gąsiorkiewicz, 2019) 
The identification of processes consists in determining the processes implemented in the enterprise and their classification. Processes are usually grouped into two or three groups. This division into two groups (basic and auxiliary processes) is recommended by professional organizations such as the APQC (American Productivity and Quality Center) as well as by some specialists (e.g., M. Porter). The second solution divides processes into three groups: basic processes (executive, operational), auxiliary processes (supporting, service) and management processes. Such a division is recommended by some professional organizations dealing with process management, such as the EABPM (European Association of Business Process Management) in their Business Process Management Common Body of Knowledge (BPM CBOK) standard. The process architecture of insurance activities (broken down into three groups of processes) is shown in Fig. 1.

The process architecture of insurance activities presented in Fig. 1 relates to 'other personal and property insurance companies'. After some modifications, it can also be used in life insurance companies.

The next stage of implementing process management is process modelling. The subject of modelling can be basic, auxiliary (supporting) and management of economic processes, but also their component parts (processes, sub-processes, actions). In the latter part of this study, attention will be focused - in the framework of the financial management process - on one of the most important auxiliary (support) processes determining the financial stability of insurance companies.

\section{Model of the process of the financial management of insurance companies}

The model of the financial management process according to management levels is presented in Fig. 2.

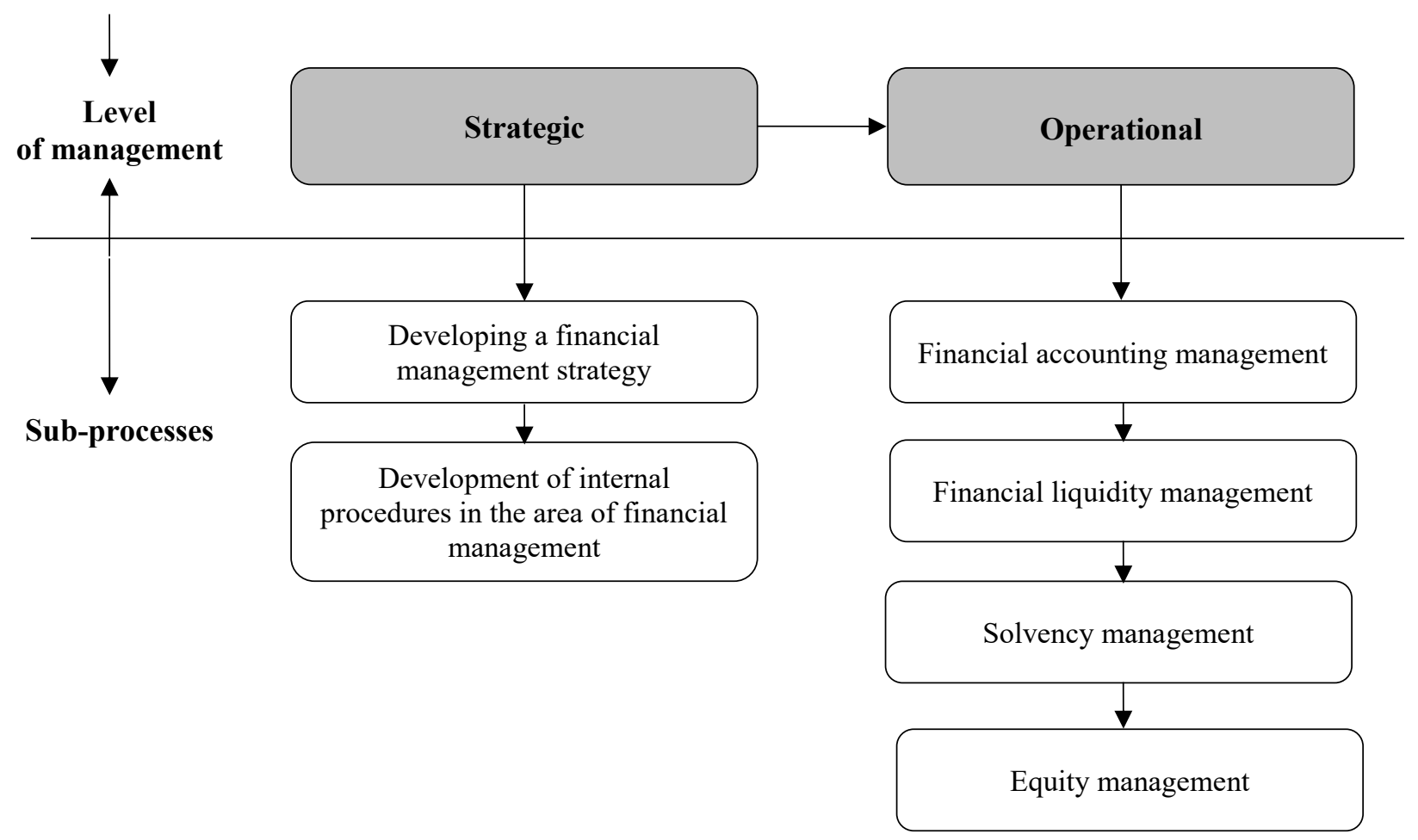

Figure 2. Model of the process of the financial management of insurance companies (Source: Authors' own research) 


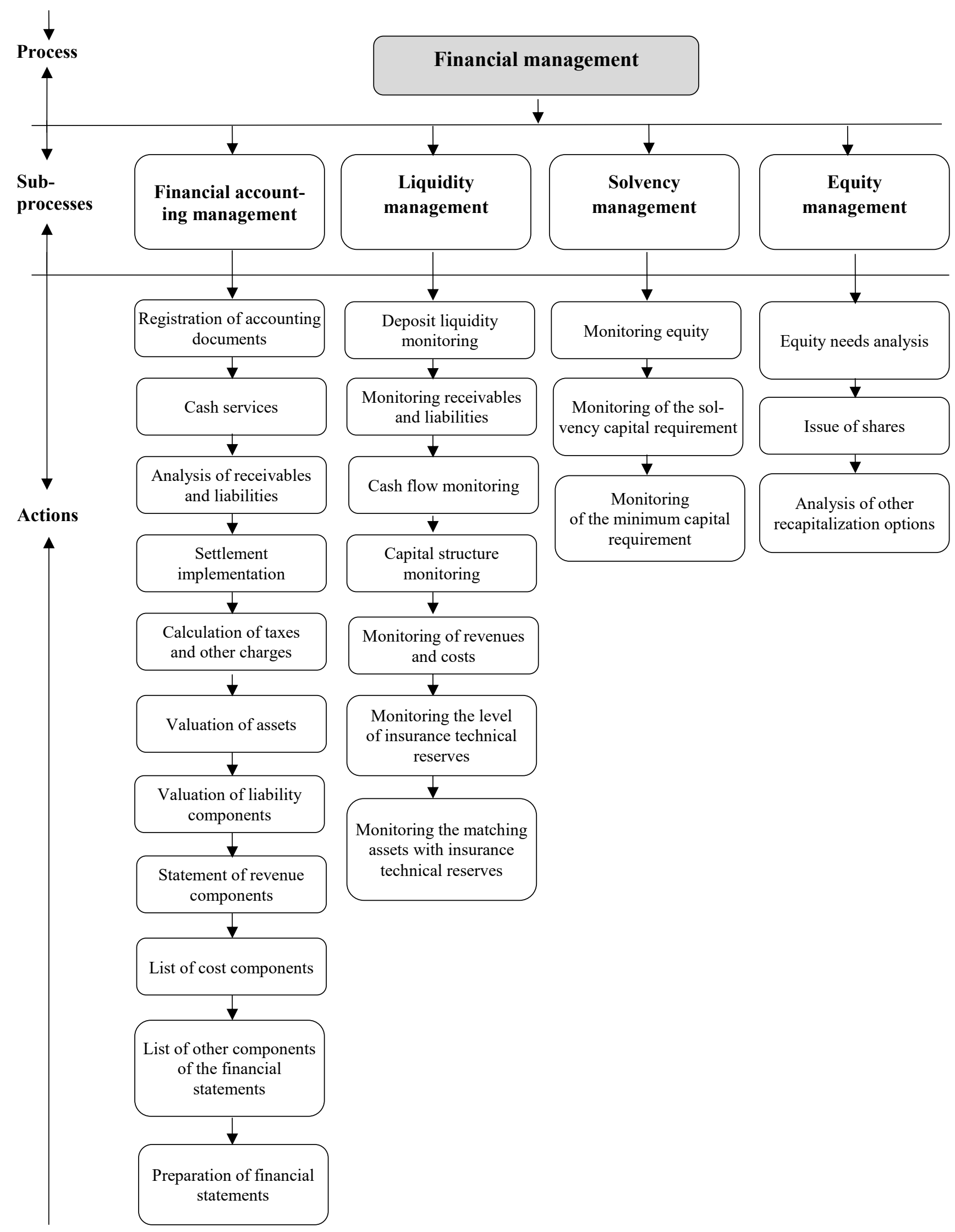

Figure 3. Model of the operational level of the financial management process

(Source: Authors' own research) 
In the financial management process model, one can distinguish strategic and operational management levels. As part of the strategic level, one can distinguish the following sub-processes: developing a financial management strategy and developing internal procedures in the area of financial management. An insurance firm should have a financial management strategy set up that is appropriate to the size of the insurance firm and the size of its activities. This strategy should be consistent with the overall business strategy of the insurance firm. As part of the sub-process of developing a financial management strategy, one needs to:

- define the strategic financial goals,

- take into consideration the types of insurance that the company offers,

- take into account the insurance company's development plans for the sale of insurance products,

take into account the amount of own funds held by the insurance firm, including the surplus of own funds over statutory requirements,

- take into consideration the cost of capital and the financial liquidity of the insurance firm,

- take into account the forecast of market and economic trends for the insurance market,

- and take into account the seasonality of the sales of insurance products of an insurance firm, and so on.

As part of the sub-process of developing procedures in the field of financial management, it should be borne in mind that the developed procedures need to:

- comply with legal regulations,

- ensure the appropriateness, completeness and accuracy of the data used,

- contain rules on reporting in the area of finance,

- specify the tasks to be performed and the units/positions responsible for carrying them out,

- and be regularly reviewed and verified.

The operational level of the financial management process includes the following sub-processes: financial accounting management, financial liquidity management, solvency management and equity management. The operational level model of the financial management process is presented in Fig. 3.
The above financial management process model enables an understanding of the essence of financial management in insurance companies through the prism of implemented sub-processes and activities, as well as of the designing, integrating and improving of subprocesses and activities.

\section{The relation between the financial management process and other processes implemented in insurance companies}

There are specific relationships between the financial management process and basic, auxiliary (supporting) and management processes.

These relationships are bi-directional. Information from the basic and additional auxiliary (supporting) and management processes feed the financial management process, while information from the financial management process feeds these processes. The relationships between the financial management process and other processes implemented in insurance companies are presented in Fig. 4.

The process of managing finances is supported by information (dashed lines in Fig. 4) from the following processes: strategic planning, operational planning, insurance company management, management of processes, creation and sale of insurance products, handling of insurance claims, marketing management, management of insurance technical reserves, risk management, investment activity management, reinsurance management, internal control management, legal services and debt collection management, internal audit management, management of sets of insurance statistics, human resources management, administrative service management and IT service management.

The financial management process supports with information (solid lines in Fig. 4) the following processes: operational planning, insurance company management, creation and sale of insurance products, handling of insurance claims, risk management, investment management, reinsurance management, legal service and debt collection management, human resource management and IT service management. 


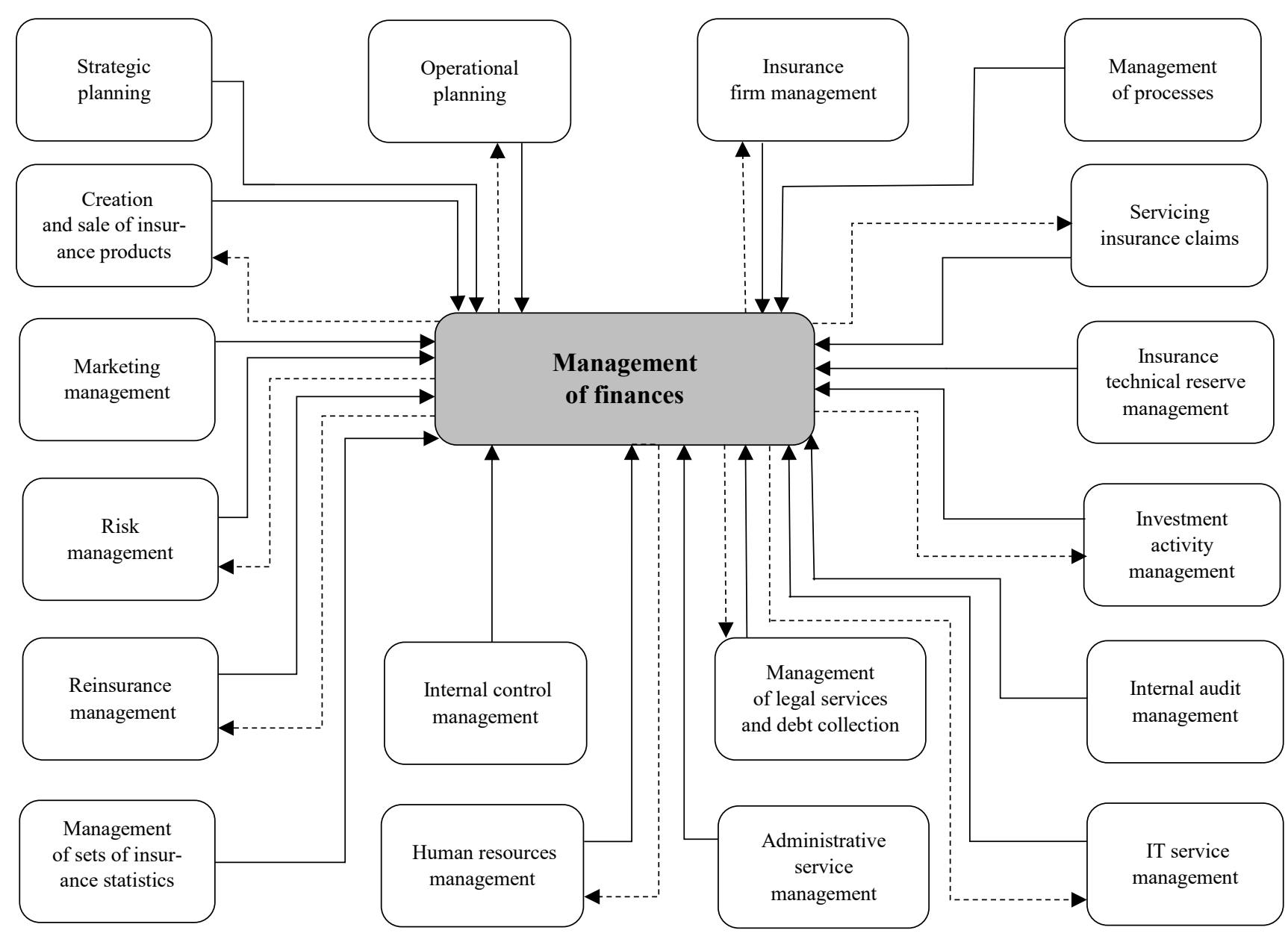

Figure 4. The relationship between the financial management process and other processes implemented in insurance companies (Source: Authors' own research)

\section{$7 \quad$ Measures to assess the financial standing of insurance companies and the process of managing their finances}

The assessment of the financial standing of insurance companies and the process of managing their finances can be carried out using the examples of measures presented in Table 2.

The most important measures of the assessment of the financial management process of insurance companies are the first two, which are statutory measures of solvency. Solvency according to the International Association of Insurance Supervisors means the ability of insurance companies to meet their obligations under all concluded contracts at any time or in any reasonably foreseeable situation.
In accordance with the requirements of the Act on insurance and reinsurance activities (Act, 2015):

- the insurance company is required to possess the allowed own funds of an amount no lower than the solvency capital requirement,

- the insurance company is required to possess the allowed own funds that are available at an amount no lower than the minimum capital requirement.

The own funds of the insurance company constitute assets free of encumbrance, available to cover losses resulting from adverse fluctuations in the area of conducted activity, both in the case of the assumption of continuing to conduct business and in the event of liquidation. The own funds of an insurance company are the sum of basic and supplementary own funds. 
Table 2. Measures for assessing the financial management process of insurance companies

(Source: Gąsiorkiewicz, 2018)

\begin{tabular}{|c|c|}
\hline Measure name & Measure formula \\
\hline $\begin{array}{l}\text { Measure of covering the capital sol- } \\
\text { vency requirement with own funds }\end{array}$ & $\frac{\text { Own resources }}{\text { Solvency capital requirement }} * 100 \%$ \\
\hline $\begin{array}{l}\text { Measure of covering the minimum } \\
\text { capital requirement with own funds }\end{array}$ & $\frac{\text { Own resources }}{\text { Minimum capital requirement }} * 100 \%$ \\
\hline $\begin{array}{l}\text { Deductible payment capability } \\
\text { measure }\end{array}$ & $\frac{\text { Technical provisions }- \text { net of reinsurance }+ \text { other creditors }}{\text { Liquid assets }} * 100 \%$ \\
\hline $\begin{array}{l}\text { Measure of securing the payment } \\
\text { of damages }\end{array}$ & $\frac{\text { Technical provisions }- \text { net of reinsurance }+ \text { capital and reserves }}{\text { Written premiums }- \text { net of reinsurance }} * 100 \%$ \\
\hline $\begin{array}{l}\text { Technical activity profitability } \\
\text { measure }\end{array}$ & $\frac{\text { Technical result }}{\text { Written premiums }- \text { net of reinsurance }} * 100 \%$ \\
\hline Return on sales measure & $\frac{\text { Net financial result }}{\text { Gross written premiums }} * 100 \%$ \\
\hline Return on equity measure & $\frac{\text { Net financial result }}{\text { Equity }} * 100 \%$ \\
\hline Return on assets measure & $\frac{\text { Net financial result }}{\text { Assets }} * 100 \%$ \\
\hline $\begin{array}{l}\text { Premium monetary efficiency } \\
\text { measure }\end{array}$ & $\frac{\text { Gross written premiums - refunds of gross written premium }}{\text { Gross written premiums }} * 100 \%$ \\
\hline Gross claims ratio & $\frac{\text { Gross claims paid }+ \text { gross change in provision for claims oustanding }}{\text { Gross earned premiums }} * 100 \%$ \\
\hline Damage deductible measure & $\begin{array}{l}\text { Claims paid - net of reinsurance }+ \text { change of the state } \\
\text { of technical provisions - net of reinsurance }\end{array}$ \\
\hline & Earned premiums - net of reinsurance \\
\hline Acquisition cost measure & $\frac{\text { Acquisition costs }}{\text { Gross written premiums }} * 100 \%$ \\
\hline Administrative expenses measure & $\frac{\text { Administrative expenses }}{\text { Gross written premiums }} * 100 \%$ \\
\hline Insurance activity cost measure & $\frac{\text { Net }- \text { operating expenses }}{\text { Gross written premiums }} * 100 \%$ \\
\hline $\begin{array}{l}\text { Cost ratio for the financial manage- } \\
\text { ment process in administrative costs }\end{array}$ & $\frac{\text { Costs of the financial management process }}{\text { Administrative expenses }} * 100 \%$ \\
\hline $\begin{array}{l}\text { Ratio of the financial management } \\
\text { cost dynamic }\end{array}$ & $\frac{\text { Costs of the financial management process at the end of the period }}{\text { Costs of the financial management process at the beginning of the period }} * 100 \%$ \\
\hline
\end{tabular}


The supervisory authority confirms, by way of decision, the amounts of ancillary own-fund items taken into account when determining the insurance company's own funds; hence, the term 'authorized own funds' is used in statutory solvency measures.

The solvency capital requirement is calculated to ensure that all measurable types of risks to which the insurance company is exposed are taken into account. The solvency capital requirement includes concluded insurance contracts and also those insurance contracts, which are expected to start within the next twelve months.

The minimum capital requirement corresponds to the amount of allowed basic own funds, below which the insurer and the beneficiaries or entitled persons could be exposed to an unacceptable level of risk.

In the event of failure to comply with the statutory solvency measures, the Polish Financial Supervision Authority may:

- set a deadline to cover financial security indicators or demand the submission of a short-term solvency plan for approval,

- prohibit the free disposal of assets, that is, property, (order the sale or purchase of specific securities) or limit the scope of activity (e.g., prohibit sales of certain insurance products),

- introduce a trustee supervising the restoration of proper financial relations (the trustee may raise effective objections to resolutions and decisions of the Management Board and the Supervisory Board),

- introduce a receivership (the receiver takes over the rights and obligations of the management board, the supervisory board and the general meeting).

Measures:

- deductible payment capacity and collateral for the payment of damages characterize the financial liquidity of insurance companies.

- profitability of technical operations, return on sales, return on equity, return on assets - illustrate the profitability of insurance companies.

- premium monetary efficiency, gross claims and the damage deductible inform about the efficiency of insurance companies.
- acquisition costs, administrative costs, costs of insurance activities characterize the cost side of insurance activities conducted by insurance companies.

- costs of the management process in administrative costs and the cost dynamics of the financial management process present the cost side of the financial management process.

\section{Summary}

The process perception of insurance activity ensures a greater dynamism to insurance companies than in the case of classical forms of management. Process management builds consistent foundations for many observations of the activities of insurance companies, enables the tracking of decision-making processes taking place within it, evaluates the legitimacy of costs incurred, and creates premises for generating accurate cost information - important both strategically and operationally - pertaining to the implemented processes.

In the literature on the subject, one can find a number of publications in the field of insurance that present a traditional, historically grounded approach to this issue. They show that a functional approach still dominates in the management of insurance companies. Only a few authors have focused on the issues of process management in insurance companies, but their studies in this area are fragmentary and relate only to process decomposition of insurance activities. Studies on the process decomposition of insurance activities are disputable and do not take into account current legal regulations.

The presented concept of the process architecture of insurance activity as well as solutions regarding the process approach in the financial management of insurance companies seem to be exhaustive sets that also take into account current legal regulations; the changing legal and institutional environment, however, will force their modification and supplementation. At the level of specific applications, these sets should be tailored to the specific conditions of their implementation.

The problems presented in the article are complex. The author's intention was to show that insurance activity can be presented in a process approach and that 
it can be modelled in this approach. The author hopes that many of the questions and issues presented will be the subject of further studies and research and the topic of scientific discussions.

\section{References}

[1] Act, 2015. Ustawa z dnia 11 września 2015 r. o działalności ubezpieczeniowej i reasekuracyjnej (Act of 11 September 2015 on Insurance and Reinsurance Activities). Journal of Laws, 2015, pos. 1844.

[2] Adamczyk, M., Trzcieliński, S., 2003. Struktura organizacyjna przedsiębiorstwa a orientacja procesowa (Company Organizational Structure and the Process Orientation). Poznań: Zeszyty Naukowe Politechniki Poznańskiej, No. 37, pp.5-14.

[3] Balanescu, V., Voicu, L., Beliciu, V., 2014. Business Process Management: A Strategic Option for the Banking Sector. Revista Economica, Vol. 66, No. 1, pp.153-163.

[4] Becker, J., Delfmann, P., Dietrich, H.A., Steinhorst, M., Eggert M., 2016. Business Process Compliance Checking - Applying and Evaluating a Generic Pattern Matching Approach for Conceptual Models in the Financial Sector. Information Systems Frontiers, Vol. 18, No. 2, pp.359-405.

[5] Bitkowska, A., 2019. Od klasycznego do zintegrowanego zarzadzania procesowego $w$ organizacjach (From Classical to Integrated Process Management in Organizations). Warsaw: Wydawnictwo C.H.Beck.

[6] Borowiecki, R., Kiełtyka, L., (ed.), 2011. Przetomy $w$ zarzadzaniu. Zarzadzanie procesowe (Breakthroughs in Management. Process Management). Toruń: TNOiK "Dom Organizatora".

[7] Burlton, R., 2001. Business Process Management: Profiting From Process. SAMS.

[8] Chang, J.F., 2006. Business Process Systems. Strategy and Implementation. New York: Auerbach Publications.

[9] Cyfert, S., 2006. Strategiczne doskonalenie architektury procesów $w$ zarządzaniu przedsiębiorstwem (Strategic Improvement of Process Architecture in the Management of a Company). Poznań: Wydawnictwo Akademii Ekonomicznej w Poznaniu.
[10] Dalikova, P., Dolezalova, V., 2012. SMEs' Process Management Differences within Various Business Sectors. Polish Journal of Management Studies, Vol. 6, No. 1, pp.184-195.

[11] Davenport, T.H., 1994. Managing in the New World of Process. Public Productivity \& Management Review, Vol. 18, No. 2, pp.133-147.

[12] Gasiorkiewicz, L., 2018. Podstawy zarzadzania procesami w zaktadach ubezpieczeń (Basics of Process Management in Insurance Companies). Warsaw: Oficyna Wydawnicza Politechniki Warszawskiej.

[13] Gąsiorkiewicz, L., 2019. The Process Architecture of the Insurance Business. Journal of Business and Economic Development, Vol. 4, No. 2, pp.44-52. DOI: 10.11648/j.jbed.20190402.12.

[14] Grajewski, P., 2012. Procesowe zarzadzanie organizacja (Process Management Organization). Warsaw: PWE.

[15] Hammer, M., Stanton, S., 1999. How Process Enterprises Really Work. Harvard Business Review, November-December.

[16] Hofman, M., Skrzypek, E., 2010. Zarzadzanie procesowe $w$ przedsiębiorstwie (Process Management in a Company). Warsaw: Wolters Kluwer.

[17] Houy, C., Fettke. P., Loos. P., 2010. Empirical Research in Business Process - Analysis of an Emerging Field of Research. Business Process Management Journal, Vol. 16, No. 4, pp.619661.

[18] Jeston, J., Nelis J., 2011. Business Process Management: Practical Guidelines to Successful Implementations. Routledge.

[19] Klun, M., Trkman, P., 2018. Business Process Management - at the Crossroads. Business Process Management Journal, Vol. 24, No. 3, pp.786-813.

[20] Nosowski, A., 2010. Zarzadzanie procesami winstytucjach finansowych (Process Management in Financial Institutions). Warsaw: C.H. Beck.

[21] Nowosielski, S., 2009. Modelowanie procesów gospodarczych w literaturze i praktyce. In: Podejście procesowe w organizacjach (The Modelling of Economic Processes in Literature and in Practice. In: S., Nowosielski, ed. The Process Approach in Organizations). Wrocław: Wydaw- 
nictwo Uniwersytetu Ekonomicznego we Wrocławiu, No. 52, pp.183-198.

[22] Rummler, G.A., Brache A.P., 2010. Podnoszenie efektywności organizacji (Increasing Organization Efficiency). Warsaw: Polskie Wydawnictwo Ekonomiczne.

[23] Simões, D., Thuan, N.H., Jonnavithula, L., Antunes, P., 2015. Modelling Sensible Business Processes. Future Data and Security Engineering. Part of the Lecture Notes in Computer Science book series (LNCS, Vol. 9446).

[24] Śliwiński, A., Karmańska, A., Michalski, T., 2015. Insurance Innovation Assessment Model - Process Based Approach (Part 1). Bangkok: ToKnowPress.

[25] Smart, P.A., Maddern, H., Maull, R.S., 2009. Understanding Business Process Management: Implications for Theory and Practice. British Journal of Management, Vol. 20, No. 4, pp.491507.

[26] Stemberger, M.I., Kovacic, A., Jaklic, J., 2007. A Methodology for Increasing Business Process Maturity in the Public Sector. Interdisciplinary Journal of Information, Knowledge and Management, Vol. 2, pp.119-133.
[27] Szczepańska, K., Bugdol, M., ed., 2016. Podstawy zarzadzania procesami (The Basics of Process Management). Warsaw: Difin.

[28] Talwar, R., 1993. Business Re-engineering. A Strategy-Driven Approach. Long Range Planning, Vol. 26, No. 6, pp.22-40.

[29] Trocki, M., 2010. Podejście procesowe w zarządzaniu (Process Approach in Management). In: A., Sowronek-Mielczarek, ed. Wyzwania zarzadcze $w$ zmieniajacym sie otoczeniu (Management challenges in a changing environment). Warsaw: Oficyna Wydawnicza Szkoły Głównej Handlowej.

[30] Tucek, D., 2009. Theory and Practice of Business Process Management. European Financial and Accounting Journal, Vol. 4, No. 4, pp.66-83.

[31] Van Der Aalst, W.M.P., La Rosa M., Santoro, F.M., 2016. Business Process Management, Business \& Information Systems Engineering, Vol. 58, No. 1, pp.1-6.

[32] Weske, M., 2007. Business Process Management: Concepts, Languages, Architectures. Berlin: Springer-Verlag. 